\title{
Six Sigma Methodology: Is It a Success Factor for Companies?
}

\author{
Wendel Alex Castro Silva ${ }^{1}$, Luciano de Oliveira Fuscaldi Neves ${ }^{2}$, Andréia de Oliveira Santos ${ }^{3}$ \\ ${ }^{1}$ Centro Universitário Unihorizontes, Mestrado Acadêmico em Administração, Brazil \\ ${ }^{2}$ Instituto Federal de Educação Ciência e Tecnologia do Norte de Minas Gerais, Campus Araçuaí, Brazil \\ ${ }^{3}$ Centro Federal de Educação Tecnológica de Minas Gerais- CEFET-MG, Departamento de Ciências Sociais \\ Aplicadas, Brazil \\ Correspondence: Wendel Alex Castro Silva, Centro Universitário Unihorizontes, Mestrado Acadêmico em \\ Administração, Brazil.
}

\author{
Received: February 3, $2017 \quad$ Accepted: April 10,2017 Online Published: April 25, 2017 \\ doi:10.5539/ibr.v10n5p179 URL: https://doi.org/10.5539/ibr.v10n5p179
}

\begin{abstract}
This paper presents an analysis of the economic performance and profitability of companies using the Six Sigma methodology. Of the 425 Brazilian companies currently on the open market, 93 use Six Sigma. The companies were first categorised by their sectors, according to how they are classified on the capital market, and then, by their size according to the Brazilian Development Bank. The results in recent years (2011-2013) of companies that use Six Sigma were compared to the results of those that do not, based on a statistical inference test of the differences between the two populations, with unknown standard deviations and a confidence interval established at the $95 \%$ level. The findings show that, in nine sectors, the Six Sigma methodology contributes to the optimisation of processes and economic performance.
\end{abstract}

Keywords: six sigmas, economic performance, profitability

\section{Introduction}

Due to increasing competition, quality improvement practices are becoming a requirement for companies that wish to remain active in the market. These practices have as their main objective satisfying customers' needs and meeting expectations for return on shareholders' investment.

Specialists have extensively discussed methods for optimising processes and services, starting with the reduction of variability, which contributes to more efficient economic and financial results and reduces the operating costs of processes and services. Therefore, experts see the implementation of the Six Sigma $(6 \sigma)$ methodology, which uses statistical tools, as a means of reducing processes' variation, increasing productivity and profitability and cutting down on costs (Almeida, Müller, Reis, Neto \& Minervi, 2012; Andrietta \& Miguel, 2007; Antony, 2004; Cabrera Júnior, 2006; Chanade, 2009; Corrêa \& Corrêa 2011; Eckes, 2001; Roos, 2009; Trad \& Maximiano, 2009).

The case that has resulted in the greatest visibility for this methodology and has become a worldwide standard in this matter is General Electric (GE) in the United States (US). In Brazil, the most famous case is the Brasmotor Group, both for being the first company with national technology to apply $6 \sigma$ in the country and for having managed to obtain, in 1999, two years after the implementation of the $6 \sigma$ programme, financial gains in the order of 20 million Brazilian reais (Werkema, 2002).

The successful results brought about by the use of $6 \sigma$ has aroused the interest of organisations in different sectors, not only to enable improvements in the quality of products, services and processes but also to allow a significant increase in organisational performance, cultural change and human capital (Pinto, Carvalho \& Ho, 2006). The implementation of this methodology follows parameters established by pioneering companies. However, some elements such as culture, type of process and company size have been neglected, potentially undermining $6 \sigma$ 's effectiveness. This makes certain adjustments necessary (Ariante, Casadei, Guiliani, Spers \& Pizzinatto, 2005; Mergulhão, 2003) so that this methodology can be correctly adjusted for each company.

Thus, $6 \sigma$ has been applied through a comprehensive approach, aligned with the implementation of strategies that promote the improvement of business performance. This increases companies' potential competitiveness and pushes to the fore strategic and managerial initiatives that a) prioritise continuous improvement of the quality of 
products and/or services, b) enhance the capacity for innovation, even when facing the challenges of establishing competitive advantages and c) reduce costs and waste. As a result of these effects, these organisational initiatives are gaining greater prominence and attracting attention not only in the academic community but also in business environments (Berlitz \& Haussen, 2005).

In this context, some questions arise:

- Is $6 \sigma$ worth applying?

- Does this methodology improve organisations' results and growth (Chanade, 2009; Trad \& Maximian, 2009)?

- Why has so little research been done on the efficiency of this methodology?

Almeida et al. (2012) reviewed the few existing publications on $6 \sigma$, and, according to the cited authors, for the period between 2004 and 2012, only 26 publications appear in the Scientific Electronic Library Online. Based on these considerations, the overall objective of the present research was to analyse if companies that use $6 \sigma$ enjoy higher economic performance as compared with companies of the same segment that do not report using this methodology.

\section{The $6 \sigma$ Methodology}

The evolution of the $6 \sigma$ methodology, forced countries such as the US to modify, from the start, how they produce products and services (Corrêa \& Corrêa, 2011; Pande, Neuman \& Cavanagh, 2000; Ribeiro \& Caten, 2012; Summer, 2003). The initial idea was to reduce variation in products' critical features, decreasing the chances of failure to close to zero. However, the $6 \sigma$ programme surpassed the limits of mere variability reduction to become a philosophy of troubleshooting based on the Deming Cycle - initially applied in Japan - and on the use of quality tools and more accurate statistical techniques (Ribeiro \& Caten, 2012).

According to Summer (2003), after 1995, Jack Welch, the manager of GE, launched a number of quality initiatives, rigidly following the $6 \sigma$ methodology. Welch tied this approach to the company's upper hierarchy and linked the annual bonus of the 40 top executives to $6 \sigma$ goals. In this way, whoever successfully implemented quality management would rise through the ranks of GE. Up to 1995, the company had worked with an average of 35,000 defects per million opportunities (DPMO).

At that time, Welch's goal was for the company to achieve, by 2000 , the $6 \sigma$ level, namely, a hit rate of 99.99966\%. Many criticised Welch's rigid policies, but he was confident these would succeed. In 1998, GE increased its sales from 90,800 million to 100,500 million US dollars, and profits went from 8,200 to 9,300 million US dollars (Summer, 2003).

Researchers do not claim that only the $6 \sigma$ by itself caused GE's success (Summer, 2003). The methodology was applied quite intelligently, but, to achieve growth targets, $6 \sigma$ was combined with other strategies, such as globalisation, improvement in services and implementation of e-business. For Cabrera Júnior (2006), what differentiates $6 \sigma$ from other methods are not the tools used, because these are not new to the area of quality control, but the way in which the tools are combined to focus on the search for stable processes.

In this methodology, organisations' sigma level is determined, which measures the companies' general and quality performance. Thus, the higher the companies' sigma level, the higher the quality of their offer, as shown in Table 1.

Table 1. Calculation of sigma level

\begin{tabular}{lll}
\hline Revenues \% & Sigma Level & DPMO \\
\hline 30.9 & $1 \sigma$ & 690,000 \\
69.2 & $2 \sigma$ & 308,000 \\
93.3 & $3 \sigma$ & 66,800 \\
99.4 & $4 \sigma$ & 6,210 \\
99.98 & $5 \sigma$ & 320 \\
99.9997 & $6 \sigma$ & 3.4 \\
\hline
\end{tabular}

Source: Pande et al. (2000, p. 31)

The scope of a $6 \sigma$ level, namely, a hit rate of $99.9997 \%$ in its processes, takes a company to the 'world-class' quality level. This level needs to be pursued by the company in its logistics system and in related performance indicators: costs, productivity, quality, activity duration, customer service, transportation and distribution, warehousing, planning, services, materials management and people administration. The goal of all companies should be the attainment of excellence with a negligible level of failure, that is, the $6 \sigma$ level (Pande et al., 2000) 
Companies seeking to implement the $6 \sigma$ methodology are motivated by successful stories reported of its use in continuous improvement processes and by a desire to understand customers' requirements and critical inputs in processes, which are necessary to be able to respond to changes in defined specifications. Companies also desire to improve the quality of their offer; optimise process flows and productivity gains; reduce work cycles; increase productive capacity and product reliability; reduce defects, costs and waste; eliminate activities that do not add value to processes from the clients' point of view; and maximise profits to increase profitability and economic performance (Andrietta \& Miguel, 2007).

Thus, $6 \sigma$ brings quite significant financial results through the optimisation of production processes by reducing costs when the method is applied. Howe ver, improvement of a business as a whole cannot be understood only as an effort to improve quality. This becomes meaningless if no increase occurs in economic performance and profitability (Cabrera Júnior, 2005), support for strategic planning (Santos \& Martins, 2010) and organisational improvement (Arnheiter \& Maleyeff, 2005) - not only in terms of people's behaviour but also processes' behaviour.

Galvani and Carpinetti (2013) draw attention to theoretical and practical differences in the number of DPMO. To the cited authors, in practice, processes rarely keep going without changes over time. These authors forecast that, with the natural deterioration of processes, they can get out of statistical control, which results in an increase in the production of items that do not meet the defined specifications - a result for which customers will not be willing to pay. This changes process capability indicators. Galvani and Carpinetti (2013) propose that a probability of 3.4 DPMO needs to be considered, which is quite different from the theoretically ideal value of 0.002 DPMO.

Santos and Martins (2008) developed a reference model with two approaches to studying $6 \sigma$ in organisations. The first is a statistical approach primarily based on the concepts of the statistical process control created by Walter Andrew She wart at Bell Labs in 1924. The second approach is a strategic approach that considers $6 \sigma$ a business improvement process or strategy, acting flexibly and comprehensively through all processes, products and functions in order to improve businesses' profitability, eliminate wastes, reduce non-quality costs and improve all operations' efficiency. Thus, publications appear to seek to strengthen the managerial and strategic allusions that are implied by $6 \sigma$ practices (Chang, 2004).

However, the $6 \sigma$ methodology covers more than just quality control and accurate statistics (Welch, 1999). This methodology addresses this issue but then goes far beyond, pushing for the improvement of leadership practices by providing tools for thinking about difficult issues. At the heart of $6 \sigma$ lies an idea capable of totally changing companies' logistics. By concentrating on customer-facing views and goals, the focus is taken away from the organisations in question, namely, companies look beyond processes and focus on clients.

Summer (2003) underlines the perennial question of what is new about $6 \sigma$, so researchers need to discover what distinguishes this methodology from others and demonstrate the advantages of its implementation. Unlike total quality management, $\sigma \sigma$ is based on numbers, facts and data, which makes it more result oriented.

Arnheiter and Maleyeff (2005) highlight the importance of the role of company employees in $6 \sigma$ improvement processes, which promote organisational improvement in both people and processes' behaviour. Thus, $6 \sigma$ is related not only to the reduction of errors but also to the development of staff's ability to implement necessary changes in their company. Another important role in $6 \sigma$ projects is played by customers since, by increasing their satisfaction, companies can also increase their profits.

Among other things, market leadership is commonly thought to be the basis for $6 \sigma$ 's success (Antony \& Banuelas, 2002; Blakeslee Jr., 2001; Eckes, 2001; Harry \& Schroeder, 2006; Ho, Chang \& Wang, 2004; Pande et al., 2000; Werkema, 2002). Another critical factor often pointed out for success is the proper choice of projects. (Adams, Gupta \& Wilson, 2003; Harry \& Schroeder, 2006; Pande et al., 2000; Perez-Wilson, 1999). However, aspects such as cultural changes (Galvani, 2010) and greater commitment - not only among top management but also all employees involved in this process (Eckes, 2001) - allow $6 \sigma$ programmes to succeed or fail.

Trad and Maximiano (2009) point out that, in recent decades, empirical gains in the area of production and operations management have come mainly from practical developments, not academic developments. Practical development is caused by highly competitive markets, whether international or national. These markets require companies to provide rapid responses to adapt to new global economic scenarios, and this speed requires academic researchers to be always attentive to new management practices that arise in Brazil and worldwide.

In addition, the $6 \sigma$ process's variability is one of the most studied topics in management. Given organisations' need to achieve the best results, this is a much researched topic since $6 \sigma$ can contribute significantly to 
organisations' success. The use of statistical metrics helps reduce process variability (Hoff, 2005). The $6 \sigma$ method's benefits are the main factors that attract organisations' interest (Andrietta \& Miguel, 2007). Along these lines, Júnior and Lima (2010) report that several organisations have generated significant revenues by implementing this methodology. Marzagão, Lopes, Gouvea and Carvalho (2014) point out that the critical success factors of $6 \sigma$ have been explored by authors in the literature on corporations. The present study emphasises the academic relevance of this research since the use of $6 \sigma$ in Brazil is relatively recent, which provides an opportunity for further studies to address the related issues. The main proposed hypothesis is that Brazilian corporations that use this methodology are more efficient, and, consequently, they benefit from higher operating performance.

\section{Research Methodology}

The present research was quantitative (Richardson, 1999), descriptive (Diehl \& Tatim, 2006) and documentary. Its universe was Brazilian companies with shares listed on the stock market, especially those that have reported using $6 \sigma$. The data were collected from these companies' annual reports, websites, annual social reports, replies to emailed questions, queries about clients of consultancies specialising in $6 \sigma$ and participation in regional and national events related to this methodology between July 2013 and February 2014.

Further data were collected from the Economatica ${ }^{\circledR}$ database and from publications of the Brazilian Securities Commission, from which information was obtained about companies' financial performance, focusing on the period between 2011 and 2013. After this survey, the selected companies (i.e. 425 companies with shares on the capital market) were stratified first by sector, according to the classification system used by the São Paulo Stock Exchange, next, by size, according to the criteria of the Brazilian Development Bank (BNDES) and, last, by use or non-use of $6 \sigma$. Subsequently, the companies' economic performance and profitability metrics were collected. Then, the averages were calculated for each sector by company size. Finally, these averages were compared between companies using or not using the $6 \sigma$ methodology.

To measure the companies' operational performance, the following metrics were used:

- $\quad$ Earnings before interest and taxes $(\triangle \mathrm{EBIT})$, which measures net operating revenue after subtracting costs and operating expenses but before subtracting depreciation and amortisation (Hoji, 2004)

- Gross margin, which indicates if companies have economies of scale in implementations of investments, providing a measure of the companies' cost structure control (Kayo \& Famá, 2004)

- Net margin, which signals if companies have improved their managerial, financial and operational efficiency, increasing the percentage of profit in relation to revenue, representing potential cash flow generated by operating activities of companies - free of tax - so the $\triangle \mathrm{EBIT}$ margin is calculated in relation to total assets, as the result of the division of profit before interest and taxes by total assets (Assaf Neto, 2007)

Company growth was measured by with the following profitability indices (Assaf Neto, 2007):

- Return on assets or the division of net income by total assets, which expresses the overall efficiency of companies in generating profits through their asset structure

- Return on investment, which results from dividing the profit generated by average investment assets

- Return on equity, which is one of the fundamental ratios used in financial analyses and is the result of dividing the net income by the average shareholders' equity

The present study adopted a conservative assumption that no differences exist between the results of companies that do or do not use the methodology. In addition, an alternative hypothesis was proposed that, with the use of $6 \sigma$, organisations improve their performance and growth and increase their indicators of economic performance and profitability compared to companies that do not use the same methodology.

Thus, sample standard deviations were used in order to estimate the population standard deviations. In this case, the estimation procedure followed Student's t-distribution and not a normal distribution since the population standard de viations were not known (Anderson, Sweeney \& Williams, 2008). Statistical Package for the Social Sciences software was also used to support the analyses. In tests of significance of sample averages, the null hypothesis was rejected, with a significance level of $5 \%(\alpha=0.05)$.

\section{Presentation and Anal ysis of Results}

Therefore, using Economatica ${ }^{\circledR}$ software, the 425 companies with shares on the capital market were selected and each of their websites were checked for information about the use of $6 \sigma$. Out of 425 companies, $22 \%$ (i.e. 93 companies) reported using this methodology. 
After distributing companies that use $6 \sigma$ by sector, the following classification was obtained: 14 in machinery, equipment, vehicles and spare parts; 14 in metallurgy; 10 in textile and clothing; 7 in civil construction and materials for construction and decoration; 5 in transportation and logistics; 5 in electricity; 5 in wholesale and retail commerce; 4 in food; 4 in communications and information technology; 3 in mineral extraction; 3 in pharmaceuticals and hygiene; 3 in pulp and paper; 2 in banking; 3 in telecommunications; 2 in agriculture (i.e. sugar, alcohol and sugar cane); 1 in beverages and tobacco; 1 in toys and leisure; 1 in packaging; 1 in oil and gas and 1 without a primary sector.

Machinery and equipment sector: Following this classification, the two averages of indicators of economic performance and profitability were compared for companies of this sector, using the BNDES's size criteria. The following results were obtained: $47.8 \%$ of these companies are classified as large, $4.3 \%$ as medium-large, $21.7 \%$ as medium-sized, $13 \%$ as small and $8.7 \%$ as micro-companies. A further $4.3 \%$ are classified as undefined because they do not disclose their annual gross revenue data.

After separating the companies of this sector by size, the following results were obtained: all the large and medium-large companies - a total of 12 - use the $6 \sigma$ methodology, as do two out of the five medium-sized companies. None of the five companies classified as small, micro or undefined use the methodology. Therefore, we analysed only the differences between the average indicators of the medium-sized companies in this sector. The other 12 companies in this sector using $6 \sigma$ were not analysed since no comparison was possible between companies that do or do not use $6 \sigma$ within the same size category. Notably, the selected sector's companies were among the first to implement this methodology in Brazil.

After this last classification, the economic performance indicators of this sector's medium-sized companies were compared. The analysis revealed that the indicators are higher in the companies using the methodology, which means they show better operational performance and efficiency. As for the profitability indicators, $44 \%$ are higher in the companies using the methodology, $44 \%$ are equal and $12 \%$ are lower. A general assessment of indicators revealed that $72.23 \%$ of the values have increased in the companies using the methodology, $22.22 \%$ have equal values and $5.55 \%$ show lower values.

Metallurgy and steel sector: In this category, $50 \%$ of the companies are classified as large, $28.6 \%$ as medium-large, $7.1 \%$ as medium-sized, $3.6 \%$ as small and $10.7 \%$ as undefined because they do not disclose their annual gross revenue data. Ten out of the 14 large companies $(71.42 \%)$, three out of eight medium-large companies $(37.5 \%)$, none of the medium-sized companies and one small company apply the $6 \sigma$ methodology. Thus, only the differences between the indicators of the large and medium-large companies were analysed in this sector.

In this sector, economic performance indicators are higher in companies using the methodology in $33.33 \%$ of the cases and equal in $66.67 \%$, which does not provide evidence that operational performance and efficiency are higher in the companies using $6 \sigma$.

As for profitability indicators, $44 \%$ have increased in the companies using the methodology, $44 \%$ are equal and $12 \%$ are lower. We were not able to check if overall efficiency, effectiveness in resource allocation and return generated are higher in companies that use the methodology.

As for medium-large companies in this category, economic performance indicators are higher in $44.45 \%$ of the companies using the $6 \sigma$ methodology and they are the same in $55.55 \%$. However, we were unable to confirm whether operational performance and efficiency are higher in companies that use the methodology. As for profitability indicators, an increase in $55.56 \%$ was observed in the companies using $6 \sigma$, while $44.44 \%$ remain equal - failing to show clearly higher overall efficiency, effectiveness in resource allocation and return generated in companies using this methodology.

Textile and clothing sector: This category includes 29 companies of which $55.2 \%$ are large, $17.2 \%$ are medium-large, $6.9 \%$ are medium-sized, $10.3 \%$ are small and $10.3 \%$ are undefined. In terms of application of the $6 \sigma$ methodology, 10 out of the 16 large enterprises use the methodology. None of the medium-large, medium and small companies use it. Therefore, we compared only the large companies' economic performance indicators, finding that economic performance indicators are higher in $88.89 \%$ of the companies using $6 \sigma$ and are equal in $11.11 \%$. We concluded that operational performance and efficiency are better in companies using this methodology.

As for profitability indicators, $44.45 \%$ of them are higher in companies using the $6 \sigma$ methodology, and $55.55 \%$ are equal. This shows that o verall efficiency, effectiveness in resource allocation and return generated are higher in companies that use $6 \sigma$. 
Civil construction and construction and decoration materials sector: This category includes 48 companies. Large organisations make up 61.4\%, 13.6\% are medium-large, $2.3 \%$ are medium-sized, $6.8 \%$ are small and $15 \%$ are undefined. We found that only seven large companies use the $6 \sigma$ methodology. Therefore, only the large companies were analysed, by which we verified that economic performance indicators are higher in $44.44 \%$ of the companies using $6 \sigma$. In $44.44 \%$ of the cases, the indicators are equal, while $11.12 \%$ are lower. We found that operational performance and efficiency are better in companies that use this methodology. As for profitability indicators, $55.56 \%$ of them are higher in companies that use the $6 \sigma$ methodology, $33.33 \%$ are equal and $11.11 \%$ are lower, which shows that overall efficiency, effectiveness in resource allocation and return generated are higher in companies that use this methodology.

Electricity sector: This consists of 46 companies of which $78.3 \%$ are large, $6.5 \%$ are medium-large and $15.2 \%$ are undefined. After grouping these by application of the $6 \sigma$ methodology, we found that five companies using $6 \sigma$ are large, out of a total of 36 large businesses.

An analysis of these large companies' indicators showed that economic performance indicators are higher in $11.12 \%$ of the companies using $6 \sigma$. The indicators are equal in $55.55 \%$ and lower in $33.33 \%$ of the cases. Thus, the application of this methodology has not brought improvements in operational performance and efficiency because these indicators are not higher for this sector's companies.

As for profitability indicators, $55.56 \%$ of these have risen in companies that use the $6 \sigma$ methodology, $33.33 \%$ are equal and $11.11 \%$ are lower, showing that overall efficiency, effectiveness in resource allocation and return generated are higher in companies that use $6 \sigma$. In general, indicators are higher in $33.34 \%$ of the companies applying this methodology, but $44.44 \%$ are equal and $22.22 \%$ lower, showing that this methodology's application has not improved indicators. However, notably, this is a reality experienced by just five companies that use $6 \sigma$, since the other 31 company do not use it.

Transportation and logistics sector: This includes 22 companies, of which $68.2 \%$ are large, $4.5 \%$ medium-sized and $27.3 \%$ undefined. All the companies that use the $6 \sigma$ methodology are large, that is, 5 out of 15 companies (33.33\%). In this sector, economic performance indicators are higher for companies using $6 \sigma$ in $22.23 \%$ of the cases, while the indicators are equal in $44.44 \%$ and lower in $22.22 \%$ of the cases. Thus, these indicators do not show that the use of this methodology has brought better results.

As for profitability indicators, in $55.56 \%$ of companies using $6 \sigma$, these have increased, $33.33 \%$ are equal and 11.11 are lower, showing that overall efficiency, effectiveness in resource allocation and return generated are higher in companies that use the methodology. Regarding the indicators in general, 38.89\% are higher for companies that apply this methodology, $44.44 \%$ are equal and $16.67 \%$ lower. That is, companies that use the $6 \sigma$ methodology overall do not have higher profitability and economic performance than companies that do not use $6 \sigma$. However, notably, only about five companies are using this methodology and 15 are not.

Wholesale and retail commerce sector: This consists of 18 companies of which $94.4 \%$ are large and $5.6 \%$ are undefined. Five out of the 18 companies (28.54\%) apply the $6 \sigma$ methodology.

Economic performance indicators are higher in companies that use $6 \sigma$ in $11.12 \%$ of the cases, but the indicators are the same in $33.33 \%$ of the cases and lower in $55.55 \%$. Thus, these indicators show that results are worse for companies that use this methodology. As for profitability indicators, $33.34 \%$ of them are higher in companies that use the $6 \sigma$ methodology, $33.33 \%$ are equal and $33.33 \%$ are lower, showing that overall efficiency, effectiveness in resource allocation and return generated are not higher in companies that use $6 \sigma$.

As for the indicators in general, they are higher for $22.23 \%$ of the companies that use this methodology, $33.33 \%$ equal and $44.447 \%$ lower. That is, companies using the $6 \sigma$ methodology have a worse profitability and economic performance than those that do not use $6 \sigma$, although these are the results for only five companies using $6 \sigma$ and 13 not using it.

Food sector: Here, $68.8 \%$ of companies are large, and $31.3 \%$ are undefined. All companies using the $6 \sigma$ methodology are large (i.e. four out of 11), which corresponds to $37.3 \%$. Economic performance indicators are higher in companies that use the methodology in $44.45 \%$ of the cases, equal in $44.44 \%$ and lower in $11.11 \%$. Thus, these indicators do not show better company results from the use of $6 \sigma$.

Profitability indicators have increased in $33.34 \%$ of the companies that use the $6 \sigma$ methodology, $44.44 \%$ are equal and $22.22 \%$ are lower, showing that overall efficiency, effectiveness in resource allocation and return generated are not higher in companies that use this methodology. Thus, in $38.89 \%$ of the cases, in general, indicators show an increase for companies that use the methodology, for $44.44 \%$, indicators remain the same and they are lower for $16.67 \%$. That is, companies that use $6 \sigma$ do not have higher economic performance and 
profitability indicators than companies that do not. However, these results are based on only four companies using this methodology versus 11 that do not use it.

Pulp and paper sector: This includes six companies, of which $83.3 \%$ are large and $16.7 \%$ are medium-large. Three of the five large companies use the $6 \sigma$ methodology.

Economic performance indicators are higher in $55.56 \%$ of companies that use $6 \sigma$, equal in $11.11 \%$ and lower in $33.33 \%$. Thus, the indicators show that the results are better for companies that use this methodology.

As for profitability indicators, $22.23 \%$ of them are higher in companies that use the $6 \sigma$ methodology, $55.55 \%$ are equal and $22.22 \%$ are lower. This shows that overall efficiency, effectiveness in resource allocation and return generated are not higher in companies using this methodology.

In general, indicators are higher in $38.89 \%$ of the companies that use $6 \sigma$, equal in $33.33 \%$ and lower in $27.77 \%$. That is, companies that use this methodology have better economic performance and profitability than those that do not use $6 \sigma$. This comparison was made between three companies that use the $6 \sigma$ methodology and two that do not.

Telecommunications sector: Here, $53.3 \%$ of companies are large, $40 \%$ are undefined and $6.7 \%$ are small. The companies that use $6 \sigma$ are all large (i.e. two out of the 16 companies or $12.5 \%$ ).

Economic performance indicators are higher for $44.45 \%$ of companies that use this methodology and equal in $55.55 \%$. Thus, these indicators do not clearly show that results are better for companies that use the $6 \sigma$ methodology.

As for profitability indicators, $33.34 \%$ of these are higher in companies that use $6 \sigma, 44.44 \%$ are equal and $22.22 \%$ are lower, showing that overall efficiency, effectiveness in resource allocation and return generated are not higher in companies using this methodology. In general, $38.89 \%$ of indicators are higher in companies that use the $6 \sigma$ methodology, $50 \%$ equal and $11.11 \%$ lower. That is, companies that use $6 \sigma$ have the same economic and profitability performance as companies that do not use it. This comparison was made between two companies using this methodology and 14 not using it.

Agricultural sector: In this category, 50\% are large companies, $16.7 \%$ medium-large, $8.3 \%$ medium-sized and $25 \%$ undefined. Only one medium-sized company uses the methodology, which precluded a comparison between companies by size and use of $6 \sigma$.

Banking sector: Here, of 25 companies, $32 \%$ are large and $68 \%$ undefined. Only two out of the eight large companies use the $6 \sigma$ methodology.

Economic performance indicators are higher in $33.34 \%$ of the companies using this methodology, the same in $44.44 \%$ and lower in $22.22 \%$, indicating that results are no better for companies using the $6 \sigma$ methodology. Profitability indicators are higher for $11.12 \%$ of companies using this methodology, equal in $33.33 \%$ and lower in $55.56 \%$. This shows that global efficiency, effectiveness in resource allocation and return generated are lower for companies that use $6 \sigma$.

In summary, in $22.24 \%$ of the cases, indicators are higher in companies that apply this methodology, equal in $38.88 \%$ and lower in 38.88. Namely, companies that use the $6 \sigma$ methodology have a similar economic performance and profitability to companies that do not use $6 \sigma$. In this sector, only two companies use the methodology and six do not.

Beverages and tobacco sector: This category has two large companies, but only one of them uses the $6 \sigma$ methodology, making a comparison of indicators impossible. Thus, the analysis of economic performance and profitability had to be carried out without a statistical analysis.

Economic performance indicators are higher in companies using the $6 \sigma$ methodology in $100 \%$ of the cases. As for the profitability indicators, $44.45 \%$ of them are higher for the company using $6 \sigma$ and $55.55 \%$ are lower, showing that overall efficiency, effectiveness in resource allocation and return generated are lower for the company that uses this methodology.

As for the indicators in general, $72.23 \%$ of these are higher in the company applying the $6 \sigma$ methodology and $27.77 \%$ are lower. That is, the company that uses $6 \sigma$ has better economic performance and profitability than the company that does not use $6 \sigma$.

Toys and leisure sector: This includes four companies, $50 \%$ of which are medium-large, $25 \%$ medium-sized and $25 \%$ undefined. Only one medium-large company uses the $6 \sigma$ methodology. As only one company of this size uses this methodology, the test statistics were not valid for a comparison of the two samples, and, as the 
average and standard deviation are not known for this population, it was not possible to establish an interval estimate for the companies sampled.

Economic performance indicators are higher in $55.56 \%$ of the companies using $6 \sigma$ and worse in $44.44 \%$. Thus, the indicators show that the results are better in companies that use this methodology.

As for profitability indicators, $55.56 \%$ of them are higher for companies that use the $6 \sigma$ methodology, and $44.44 \%$ are lower, showing that overall efficiency, effectiveness in resource allocation and return generated are higher when $6 \sigma$ is used. In general, the indicators reveal better results for $55.56 \%$ of the companies applying the methodology and lower results in $44.44 \%$, that is, better economic performance and profitability in companies that use this methodology.

Communications and information technology sector: Here, $71.4 \%$ of the companies are large, $14.3 \%$ are medium-sized and $14.3 \%$ are undefined. Four out of the five large companies use the $6 \sigma$ methodology (80\%). Since only one company does not use the methodology, the test statistics were not valid for comparing the two samples.

Mineral extraction sector: In this category, $37.5 \%$ of the companies are large, and $62.5 \%$ are undefined. Two of the three companies use the $6 \sigma$ methodology.

Pharmaceuticals and hygiene sector: This has five companies of which $60 \%$ are large and $40 \%$ are undefined. All the large companies use $6 \sigma$.

Oil and gas sector: This category contains six companies: $83.3 \%$ large and $16.7 \%$ small firms. The only company of this sector that uses this methodology is large, accounting for $20 \%$ of this sector.

Companies without a primary segment: This includes 43 companies. Of these, $18.61 \%$ are large, $2.3 \%$ medium-large, $2.3 \%$ medium-sized, $2.3 \%$ small and $74.4 \%$ undefined. In this and the previous three sectors, we could not compare companies' economic performance and profitability indicators.

The analyses further showed that nine sectors do not have companies that use the $6 \sigma$ methodology. These include stock, commodities and futures exchange; real estate credit; education; print shops and publishers; hotels and tourism; financial intermediation; sanitation, water and gas services; and medical services.

\section{Conclusion}

The methodology - quantitative and descriptive methods supported by documentary research - applied in this study was effective in achieving the research goals, since it made possible, through indirect data, analyses and comparisons of the use or non-use of $6 \sigma$ by 425 companies listed in the Brazilian open capital market. After classification of the companies by size, the results revealed that 78 (83.87\%) out of the 93 companies analysed that use the $6 \sigma$ methodology are large.

These results offer answers to the questions that motivated this study for the sectors of machinery, equipment, vehicles and spare parts; textiles and clothing; civil construction and construction and decoration materials; pulp and paper; be verages and tobacco; and toys and leisure. The indicators for operational performance, overall efficiency, effectiveness in resource allocation and return generated are higher for companies that use the $6 \sigma$ methodology compared with those that do not use it. Therefore, in the sectors studied, the use of $6 \sigma$ contributes to the optimisation of processes, thereby generating growth and improving economic performance.

In the metallurgy and steel, electricity, transportation and logistics, food, telecommunications and banking sectors, the results do not show differences between companies that do or do not apply the $6 \sigma$ methodology. Thus, the benefits brought by the use of $6 \sigma$ could not be verified for these sectors.

After an analysis of the commerce sector, the results of companies that use the $6 \sigma$ methodology are lower than those of companies that do not use it. Since the application and implementation of $6 \sigma$ were not evaluated, we were unable to verify the causes of this result. In the communications and information technology, mineral extraction, pharmaceuticals and hygiene, agriculture, packaging and oil and gas sectors, as well as companies without a primary segment, a comparison was not possible as not enough companies were available.

In view of these results, we conclude that, for companies of various sectors, the $6 \sigma$ philosophy is a business strategy that is here to stay and spread, rather than just a fad. The $6 \sigma$ programme has been improved since this research was conducted, and it is being adopted by an increasing number of organisations in the machinery and equipment, metallurgy, textiles and other sectors, in which the $6 \sigma$ methodology is already predominant. However, in the agriculture, beverages and tobacco and toys sectors, $6 \sigma$ is still rarely applied. 
For the purposes of this study, the $6 \sigma$ methodology cannot be said to be a variable of success since, in this study, $6 \sigma$ could not be separated from other variables. However, notably, in the period under analysis, most companies that used this methodology showed better results than those that did not.

As for the future of $6 \sigma$ philosophy, some trends stand out, including an understanding of the synergy between $6 \sigma$ and lean manufacturing practices that has generated a methodology called Lean Six Sigma and an increased dissemination of Design for Six Sigma. The number of midsize and small companies is increasing that plan to use the philosophy after making the adjustments and simplifications necessary for their reality. The $6 \sigma$ philosophy is being implemented as a strategy for creating value for businesses and not simply for eliminating defects or reducing costs. In addition, $6 \sigma$ is being integrated with quality programmes and standards, and specific software for $6 \sigma$ management is being used in organisations and for decision-making based on factual data.

The limitations of this study include a lack of information in the Economatica ${ }^{\circledR}$ database, delays in companies' responses regarding the use of the $6 \sigma$ methodology, the limited number of companies that apply the methodology in certain sectors, ongoing mergers and acquisitions of companies and websites that were still in construction or outdated at the time of this research. Regarding future studies, the results before and after the application of the $6 \sigma$ methodology could be analysed in a sample of Brazilian companies of different sectors, to evaluate the scope of this application and to study the impact of local culture on the use of the $6 \sigma$ methodology.

\section{References}

Adams, C., Gupta, P., \& Wilson, C. (2003). Six sigma deployment. Boston: Butterworth Heinemann.

Almeida, C. A., Müller, S. I. M. G., Reis, R. A., Neto, J. C., \& Minervi, N. A. (2012). Seis Sigmas: retrato da produção científica indexada na biblioteca eletrônica Scielo. In: II CONBREPRO. Anais... Ponta Grossa.

Anderson, D. R., Sweeney, D. J., \& Williams, T. A. (2008). Estatística aplicada à administração e economia. São Paulo: Cengage Learning.

Andrietta, J. M., \& Miguel, P. A. C. (2007). Aplicação do programa Seis Sigmas no Brasil: resultados de um levantamento tipo survey exploratório-descritivo e perspectivas para pesquisas futuras. Gestão Produção, 14(2), 203-219. https://doi.org/10.1590/S0104-530X2007000200002

Antony, J. (2004). Six Sigma in the UK service organizations: results from a pilot survey. Managerial Auditing Journal, 19(8), 1006-1013. https://doi.org/10.1108/02686900410557908

Antony, J., \& Banuelas, R. (2002). Key ingredients for the effective implementation of Six Sigma program. Measuring Business Excellence, 6(4), 20-27. https://doi.org/10.1108/13683040210451679

Ariante, M., Casadei, M. A., Guiliani, A. C., Spers, E. E., \& Pizzinatto, N. K. (2005). Processo de mudança organizacional: estudo de caso Seis Sigmas. Revista FAE, 8(1), 81-92.

Arnheiter, D. A., \& Maleyeff, J. (2005).The integration of lean management and Six Sigma. The TQM Magazine, 17(1), 5-18. https://doi.org/10.1108/09544780510573020

Assaf, N. A. (2007). Finanças corporativas e valor. São Paulo: Atlas.

Berlitz, F. A., \& Haussen, M. L. (2005). Seis Sigmas no laboratório clinico: impacto na gestão de performance analítica dos processos técnicos. Bras. Patol. Med. Lab., 41(5), 301-312. https://doi.org/10.1590/S1676-24442005000500004

Blakeslee, J. J. A. (2001). Achieving quantum leaps in quality and competitiveness: implementing the Six Sigma solution in your company. ASQ's 53rd Annual Quality Congress Proceedings. USA, Anais..., 486-496.

Cabrera, J. A. (2006). Dificuldades de implementação de programas Seis Sigmas: estudos de casos em empresas com diferentes níveis de maturidade (Dissertação de Mestrado, Universidade de São Paulo, 2006). Retrieved from www.teses.usp.br/teses/disponiveis/18/18140/tde-04072006.../DissertacaoAlvaro.pdf

Chanade, W. H. L. (2009). Aplicação da metodologia Seis Sigmas para incremento da produtividade no envase de tintas decorativas. (Dissertação de Mestrado, Centro Universitário do Instituto Mauá de Tecnologia, 2009) Retrieved from maua.br/.../aplicacao-da-metodologia-seis-sigma-para-incremento-da-produtividade-no-...

Corrêa, C. A., \& Corrêa, H. L. (2011). Processo de formação de estratégias de manufatura em empresas brasileiras de médio e pequeno porte. Revista de Administração Contemporânea-RAC, 15(3), 454-475. https://doi.org/10.1590/S1415-65552011000300006

Diehl, A. A., \& Tatim, D. C. (2006). Pesquisa em ciências sociais aplicadas: métodos e técnicas. São Paulo: Pearson. 
Eckes, G. (2001). The Six Sigma revolution: how General Electric and others turned process into profits. New York: John Wiley \& Sons.

Galvani, L. R., \& Carpinetti, L. C. R. (2013). Análise comparativa da aplicação do programa Seis Sigma em processos de manufatura e serviços. Revista Produção, 23(4), 695-704. https://doi.org/10.1590/s0103-65132013005000013

Harry, M., \& Schroeder, R. (2006). Six sigma: the breakthrough management strategy revolutionizing the world's top corporations. New York: Doubleday.

Ho, Y. C., Chang, O. C., \& Wang, W. B. (2008). An empirical study of key success factors for Six Sigma Green Belt projects at an Asian MRO company. Journal of Air Transport Management, 14(5), 263-269. https://doi.org/10.1016/j.jairtraman.2008.05.002

Hoff, C. H. Y. (2005) Avaliação dos Resultados da Aplicação da Estratégia Seis Sigma em um Restaurante Industrial. (Dissertação de Mestrado, Universidade de Taubaté, 2005).

Hoji, M. (2004). Administração financeira: uma abordagem prática. São Paulo: Atlas.

Kayo, E. K., \& Famá, R. (2004). A estrutura de capital e o risco das empresas tangível-intensivas e intangível-intensivas. Revista Administração-RAUSP, 39(2), 164-176.

Marzagão, D. S. L., Lopes, A. P. V. B. V., Gouvea, M. A., Carvalho, M. M. (2014). Fatores críticos de sucesso na implementação do programa seis sigma: uma meta análise de pesquisas quantitativas. Revista de Produção Online, 14(2), 465-498. https://doi.org/10.14488/1676-1901.v14i2.1348

Mergulhão, R. C. (2003). Análise da implementação do Seis Sigmas em empresas de manufatura no Brasil. (Dissertação de Mestrado, Universidade Federal de Itajubá, 2003). Retrieved from www.teses.usp.br/teses/disponiveis/12/12139/tde-05032003-194338/pt-br.php

Mora Júnior, C. H., \& Lima, E. (2011) Descontinuidade de programas seis sigma: um estudo comparativo de casos. REGE, 18(4), 639-658. https://doi.org/10.5700/rege445

Pande, P. S., Neumann, R. P., \& Cavanagh, R. (2000). The six sigma way: how GE, Motorola and other top companies are honing their performance. New York: McGraw-Hill.

Perez-Wilson, M. (1999). Seis Sigmas: compreendendo o conceito, as implicações e os desafios. Rio de Janeiro: Qualitymark.

Pinto, S. H. B., Carvalho, M. M., \& Ho, L. L. (2006). Implementação de programas de qualidade: um survey em empresas de grande porte no Brasil Gestão \& Produção, 13(2), 191-203.

Ribeiro, J. L. D., \& Caten, C. S. T. (2012). Série monográfica Qualidade. Porto Alegre: Fundação Empresa Escola de Engenharia da UFRGS Universidade Federal do Rio Grande do Sul.

Richardson, R. J. (1999). Pesquisa Social: Métodos e Técnicas. São Paulo: Atlas.

Roos, C. (2009). Modelo de controle do desempenho Seis Sigmas em processos de produção continua. (Dissertação de Mestrado, Universidade Federal de Santa Maria, 2009).

Santos, A. B., \& Martins, M. F. (2008) Modelo de referência para estudar o Seis Sigmas nas organizações. Gestão \& Produção, 15(1), 43-56. https://doi.org/10.1590/S0104-530X2008000100006

Summer, S. (2003). Einbindug der Six Sigma-problemlösungssystematik in das Mercedes-Benz Produktionssystem unter Berücksichtigung der Unternehmens-Kultur. Fachhochschule Vorarlberg GmbH: Altach.

Trad, S., \& Maxiamiano, A. C. (2009) Seis Sigmas: fatores críticos de sucesso para sua implantação. RAC, 13(4), 647-662,

Werkema, M. C. C. (2002). Criando a cultura Seis Sigmas. Rio de Janeiro: Qualitymark.

\section{Copyrights}

Copyright for this article is retained by the author(s), with first publication rights granted to the journal.

This is an open-access article distributed under the terms and conditions of the Creative Commons Attribution license (http://creativecommons.org/licenses/by/4.0/). 